Pflügers Arch. 353, 215-225 (1975)

(C) by Springer-Verlag 1975

\title{
Regeneration in Grafts of Normal and Denervated Rat Muscles
}

\author{
Contractile Properties
}

\author{
Bruce M. Carlson and Ernest Gutmann \\ Department of Anatomy, University of Michigan, Ann Arbor, Michigan, U.S.A. \\ and Institute of Physiology, Czechoslovak Academy of Sciences \\ Prague, Czechoslovakia
}

Received September 4, 1973

Summary. The soleus or extensor digitorum longus muscles of young rats were freely grafted into the bed of the corresponding contralateral muscle. The grafts were of normal muscle or museles which had been denervated for 14 days. Grafts of normal muscle were characterized by little or no contractile activity for the first 2-4 days after transplantation. In contrast, denervated grafts contracted weakly, but consistently, throughout this early period. The patterns of contraction were complex. In early transplants, the contractions were due entirely to surviving muscle fibers in the graft, and the contractile characteristics were those of denervated muscle fibers. After the first week, contractions of newly regenerating muscle fibers within the grafts were superimposed upon and later took over those from the fibers that survived the original transplantation. The contraction times approached those of the normal soleus or extensor muscles during the second month after grafting, and the grafts contracted like fast or slow muscles.

Key words: Muscle Regeneration - Musele Transplantation - Contractile Properties of Muscle Transplants - Denervation of Musele - Rat.

It is known that the regeneration of new muscle fibers is the basis for the successful free grafting of mammalian skeletal muscles $[2,6,8,9]$. Because of the excellent morphological condition of long term muscle grafts, free transplantation represents a useful experimental model for studying the development of contractile characteristics in small mammalian fast and slow muscles. In small muscles, the degree of success with other systems for producing uniform populations of regenerating muscle fibers is unsatisfactory for studies of contractile properties. In addition to obtaining information on the restoration of contractile properties in regenerating fast and slow muscles, this study was designed to provide baseline data for further research on the contractile and histochemical characteristics of cross-transplanted muscles [3].

\section{Methods}

In over 1601 month old Wistar rats, normal or previously denervated (for 14 days) soleus (SOL) or extensor digitorum longus (EDL) muscles were freely trans- 
planted to the contralateral leg in the manner previously described [2]. During the operations the animals were anesthetized with sodium pentobarbital $(50 \mathrm{mg} / \mathrm{kg})$.

As preliminary experiments, muscles were denervated from 14-42 days before free grafting. Except for the total mass of tissue involved, the reactions of the muscles denervated for times within this range were quite similar. In the subsequent experiments involving denervation, 14 days was chosen to be the standard interval of denervation before transplantation.

Soleus. In the denervation series, 14 day denervated left SOL muscles were grafted in place of their right counterparts and removed for analysis $2,4,7,14,30$, 60 , or 90 days after transplantation. In the normal series unprepared SOL museles were similarly grafted and removed at the same intervals.

Extensor Digitorum longus. Previously denervated (14 day) and normal grafts were examined at $2,4,7,14,30$, and 60 days after free transplantation.

All transplants were removed from etherized animals and placed into a solution containing $149.8 \mathrm{mM} \mathrm{Na}+5.0 \mathrm{mM} \mathrm{K} \mathrm{K}^{+}, 2.0 \mathrm{mM} \mathrm{Ca}++, 148.0 \mathrm{mM} \mathrm{Cl}-, 12.0 \mathrm{mM}$ $\mathrm{HCO}_{3}^{-}, 1.0 \mathrm{mM} \mathrm{H}_{2} \mathrm{PO}_{4}^{-}$and $11.0 \mathrm{mM}$ glucose $(\mathrm{pH} 7.2$ ) as well as $0.01 \mathrm{M}$ tubocurarine chloride. The muscles were placed in a $36^{\circ} \mathrm{C}$ chamber with oxygenated medium, and following a $10 \mathrm{~min}$ equilibration period, they were directly stimulated with Pt electrodes. After determination of the optimal resting tension for isometric recording, recordings of contractile properties of twitch and tetanus were made with the automatic analyzer of muscle contraction properties used in our previous study [1]. The following contractile properties were recorded: twitch tension, latency period (LP-stimulus artifact to first mechanical response), maximal rate of tension development (TPC), full contraction time, or time to peak tension (FCT), half relaxation time (HRT-from peak to half amplitude of the twitch) as well as the maximal tetanic tension and the maximal rate of tetanic tension development. The maximal rate of tension development was recorded as a time parameter of contraction (TPC), or the time necessary for the development of maximal (twitch and tetanic) tension as described by Rohliček and Gutmann [5]. The TPC, as used in this report, represents the half-time of this value.

\section{Results}

Extensor Digitorum longus. Free grafts of the normal EDL muscle which had been placed into the bed of the contralateral EDL for 2 days demonstrated virtually no response to direct electrical stimulation. Of the 8 normal transplants tested at this time only a slight flicker of contraction could be evoked with stimuli of $5 \mathrm{msec}$ in duration and at the highest voltage $(26 \mathrm{~V})$. In two of the 2 day transplants no response was registered. This almost complete loss of contractility was only temporary. By 4 days after transplantation the threshold of stimulation had decreased markedly to normal values, and the amplitude of the twitch increased about 10-fold. Nevertheless, it was very low (Table 1). The contraction times of 4 day transplants were prolonged over the normal values because any functional muscle fibers were denervated from the time of transplantation. This period is yet too early for any contribution by regenerating muscle fibers to the contractile response. Following a slight peak at 14 days, at which time numerous immature regenerating muscle fibers are found in the central regions of the transplant, the contractile times 

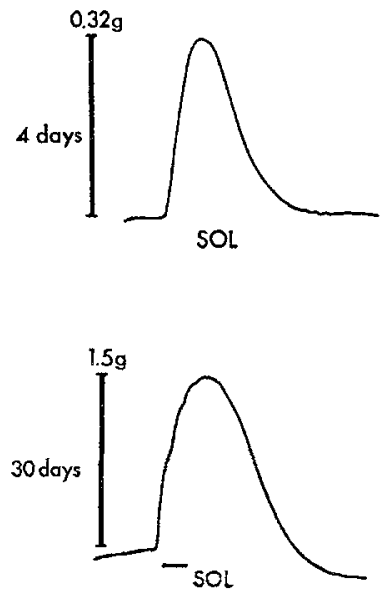



EDL

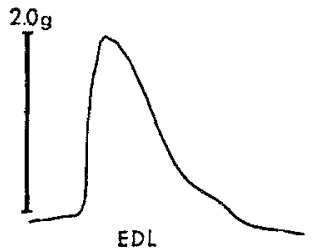

Fig.1. Oscilloscopic recording of 4 day and 30 day grafts of denervated SOL and EDL muscles. The horizontal line below the lower left curve represents $10 \mathrm{msec}$

gradually decreased to normal values by 60 days. Similar changes were recorded in the LP, TPC and HRT of the twitch as well as the TPC of tetanus. Maximal twitch and tetanic tension of the normal EDL transplants reached only about half the values of the normal EDL in 60 day rats (Table 2). The reduced tension output in older transplants of normal muscle, despite their near normal weight, is a reflection of the presence of increased amounts of collagen in the grafts. Representative twitch curves for normal EDL transplants are illustrated in Fig. 1.

Grafts of 14 day denervated EDL muscles differed from normal muscle grafts, particularly in the early days following transplantation. There was no temporary loss of the contractile response. The denervated EDL muscle graft was excitable with stimuli of $1 \mathrm{msec}$ duration and at the thresholds normally observed. The twitch tension at 2 days was $1.32 \mathrm{~g}$. At this time the components of the twitch (LP, TPC, FCT, HRT) were prolonged (Table 3 ), reflecting the denervation changes of the EDL [4]. Since at 2 days no regenerating muscle fibers are mature enough to contract, the contractile response at this time was entirely a reflection of the functional state of the surviving muscle fibers of the denervated graft.

In the denervated EDL grafts the components of the twitch reacted most slowly to stimulation on the 7th day (Table 3). This is the time when regenerating muscle fibers within the denervated graft would, according to their morphology, first be able to make their contractile response felt. Following this time there was a progressive shortening of 
Table 1. Contractile properties of free grafts of

\begin{tabular}{lllll}
\hline $\begin{array}{l}\text { Age } \\
(\text { days })\end{array}$ & $\begin{array}{l}\text { TwT } \\
(\mathrm{g})\end{array}$ & $\begin{array}{l}\text { LP } \\
(\mathrm{msec})\end{array}$ & $\begin{array}{l}\text { TPC } \\
(\mathrm{msec})\end{array}$ & $\begin{array}{l}\text { FCT } \\
(\mathrm{msec})\end{array}$ \\
\hline $\begin{array}{l}4 \\
(n=3)\end{array}$ & $0.33 \pm 0.04$ & $4.80 \pm 0.10$ & $2.80 \pm 0.15$ & $14.63 \pm 2.50$ \\
7 & & & & \\
$(n=3)$ & $1.15 \pm 0.03$ & $5.20 \pm 0.30$ & $6.37 \pm 0.30$ & $13.83 \pm 0.88$ \\
$\begin{array}{l}14 \\
(n=3)\end{array}$ & $1.35 \pm 0.56$ & $5.20 \pm 0.36$ & $5.40 \pm 0.40$ & $17.63 \pm 1.17$ \\
$\begin{array}{l}(n=5) \\
(n=\end{array}$ & $1.60 \pm 0.23$ & $4.24 \pm 0.22$ & $3.72 \pm 0.21$ & $14.28 \pm 0.20$ \\
$(n=7)$ & $7.30 \pm 2.80$ & $3.21 \pm 0.16$ & $3.97 \pm 0.21$ & $11.29 \pm 0.35$ \\
\hline
\end{tabular}

Table 2. Contractile properties of the normal extensor

\begin{tabular}{|c|c|c|c|c|}
\hline $\begin{array}{l}\text { Postnatal } \\
\text { age } \\
\text { (days) }\end{array}$ & $\begin{array}{l}\text { TwT } \\
\text { (g) }\end{array}$ & $\begin{array}{l}\text { LP } \\
\text { (msec) }\end{array}$ & $\begin{array}{l}\text { TPC } \\
\text { (msec) }\end{array}$ & $\begin{array}{l}\text { FCT } \\
\text { (msec) }\end{array}$ \\
\hline $\begin{array}{l}14 \\
(n=3)\end{array}$ & $1.63 \pm 0.18$ & $4.47 \pm 0.27$ & $4.47 \pm 0.73$ & $15.13 \pm 0.98$ \\
\hline $\begin{array}{l}30 \\
(n=3)\end{array}$ & $4.97 \pm 0.49$ & $3.63 \pm 0.03$ & $3.07 \pm 0.22$ & $11.60 \pm 0.60$ \\
\hline $\begin{array}{l}60 \\
(n=3)\end{array}$ & $12.23 \pm 0.67$ & $3.23 \pm 0.12$ & $4.37 \pm 0.26$ & $12.83 \pm 0.44$ \\
\hline $\begin{array}{l}90 \\
(n=3)\end{array}$ & $23.60 \pm 2.40$ & $3.00 \pm 0.12$ & $4.47 \pm 0.32$ & $12.67 \pm 0.75$ \\
\hline
\end{tabular}

Table 3. Contractile properties of free grafts of the

\begin{tabular}{lllll}
\hline $\begin{array}{l}\text { Age } \\
\text { (days) }\end{array}$ & $\begin{array}{l}\text { TwT } \\
(\mathrm{g})\end{array}$ & $\begin{array}{l}\mathrm{LP} \\
(\mathrm{msec})\end{array}$ & $\begin{array}{l}\text { TPC } \\
(\mathrm{msec})\end{array}$ & $\begin{array}{l}\text { FCT } \\
(\mathrm{msec})\end{array}$ \\
\hline $\begin{array}{l}2 \\
(n=5)\end{array}$ & $1.32 \pm 0.14$ & $4.68 \pm 0.11$ & $6.12 \pm 0.09$ & $20.54 \pm 0.33$ \\
$\begin{array}{l}4 \\
(n=4)\end{array}$ & $3.30 \pm 0.93$ & $4.38 \pm 0.18$ & $6.15 \pm 0.31$ & $19.85 \pm 0.35$ \\
7 & & & \\
$(n=5)$ & $3.21 \pm 0.29$ & $4.48 \pm 0.12$ & $8.18 \pm 0.12$ & $24.00 \pm 0.60$ \\
$\begin{array}{l}14 \\
(n=4)\end{array}$ & $4.67 \pm 0.58$ & $4.20 \pm 0.20$ & $7.70 \pm 0.47$ & $21.28 \pm 0.92$ \\
$\begin{array}{l}30 \\
(n=5)\end{array}$ & $8.75 \pm 1.27$ & $3.40 \pm 0.13$ & $4.36 \pm 0.51$ & $14.90 \pm 0.91$ \\
$\begin{array}{l}60 \\
(n=4)\end{array}$ & $13.14 \pm 4.36$ & $3.53 \pm 0.25$ & $3.30 \pm 0.29$ & $11.97 \pm 0.30$ \\
\hline
\end{tabular}


the normal extensor digitorum longus muscle

\begin{tabular}{llll}
\hline $\begin{array}{l}\text { HRT } \\
(\mathrm{msec})\end{array}$ & $\begin{array}{l}\text { TetT } \\
(\mathrm{g})\end{array}$ & $\begin{array}{l}\text { Tet TPC } \\
(\mathrm{msec})\end{array}$ & $\begin{array}{l}\text { Wt } \\
(\mathrm{mg})\end{array}$ \\
\hline $15.57 \pm 0.08$ & $1.21 \pm 0.03$ & & \\
$13.83 \pm 1.48$ & $1.93 \pm 0.58$ & $58.00 \pm 0.15$ & \\
$17.77 \pm 1.53$ & $5.45 \pm 0.53$ & $66.40 \pm 2.60$ & \\
$24.86 \pm 6.16$ & $13.50 \pm 3.57$ & $36.68 \pm 4.66$ & $59.40 \pm 7.26$ \\
$11.82 \pm 1.21$ & $85.45 \pm 15.00$ & $28.72 \pm 1.50$ & $123.12 \pm 9.75$ \\
\hline
\end{tabular}

digitorum longus muscle (ontogenic gradient)

\begin{tabular}{llll}
\hline HRT & TetT & Tet TPC & Wt \\
$(\mathrm{msec})$ & $(\mathrm{g})$ & $(\mathrm{msec})$ & $(\mathrm{mg})$ \\
\hline $18.37 \pm 1.38$ & $12.50 \pm 2.70$ & $73.13 \pm 14.47$ & $8.17 \pm 0.67$ \\
$8.47 \pm 0.09$ & $35.0 \pm 1.97$ & $21.53 \pm 1.85$ & $31.67 \pm 0.88$ \\
$13.53 \pm 0.69$ & $93.87 \pm 8.24$ & $43.10 \pm 9.62$ & $71.67 \pm 2.33$ \\
$11.37 \pm 1.53$ & $175.7 \pm 7.0$ & $30.00 \pm 3.79$ & $131.3 \pm 8.97$ \\
\hline
\end{tabular}

14-day denervated extensor digitorum longus muscle

\begin{tabular}{llll}
\hline $\begin{array}{l}\text { HRT } \\
(\mathrm{msec})\end{array}$ & $\begin{array}{l}\text { TetT } \\
(\mathrm{g})\end{array}$ & $\begin{array}{l}\text { Tet TPC } \\
(\mathrm{msec})\end{array}$ & $\begin{array}{l}\text { Wt } \\
(\mathrm{mg})\end{array}$ \\
\hline $22.80 \pm 0.37$ & $2.55 \pm 0.25$ & $18.80 \pm 0.80$ & \\
$20.08 \pm 0.35$ & $11.30 \pm 6.40$ & $28.70 \pm 5.50$ & \\
$26.98 \pm 2.02$ & $10.62 \pm 3.48$ & $34.46 \pm 5.20$ & \\
$21.60 \pm 1.58$ & $15.50 \pm 0.69$ & $33.65 \pm 6.95$ & \\
$19.46 \pm 1.94$ & $64.20 \pm 12.06$ & $44.90 \pm 8.53$ & $76.50 \pm 1.26$ \\
$11.35 \pm 0.22$ & $64.95 \pm 28.51$ & $47.47 \pm 1.06$ & $98.75 \pm 17.30$ \\
\hline
\end{tabular}


Table 4. Contractile properties of free

\begin{tabular}{|c|c|c|c|c|}
\hline $\begin{array}{l}\text { Age } \\
\text { (days) }\end{array}$ & $\begin{array}{l}\mathrm{Tw} \mathbf{T} \\
(\mathrm{g})\end{array}$ & $\begin{array}{l}\mathrm{LP} \\
(\mathrm{msec})\end{array}$ & $\begin{array}{l}\text { TPC } \\
\text { (msec) }\end{array}$ & $\begin{array}{l}\text { FCT } \\
\text { (msec) }\end{array}$ \\
\hline $\begin{array}{l}4 \\
(n=5)\end{array}$ & $0.61 \pm 0.11$ & $5.63 \pm 0.20$ & $12.40 \pm 1.20$ & $34.04 \pm 2.50$ \\
\hline $\begin{array}{l}7 \\
(n=3)\end{array}$ & $1.03 \pm 0.20$ & $5.27 \pm 0.03$ & $11.17 \pm 0.17$ & $33.66 \pm 2.03$ \\
\hline $\begin{array}{l}14 \\
(n=3)\end{array}$ & $5.78 \pm 0.35$ & $4.37 \pm 0.15$ & $10.00 \pm 0.15$ & $27.33 \pm 0.75$ \\
\hline $\begin{array}{l}30 \\
(n=4)\end{array}$ & $1.61 \pm 0.40$ & $4.63 \pm 0.28$ & $9.22 \pm 0.96$ & $26.60 \pm 0.31$ \\
\hline $\begin{array}{l}60 \\
(n=4)\end{array}$ & $2.02 \pm 0.35$ & $4.17 \pm 0.23$ & $6.40 \pm 1.05$ & $19.15 \pm 2.88$ \\
\hline $\begin{array}{l}90 \\
(n=4)\end{array}$ & $3.52 \pm 0.87$ & $3.20 \pm 0.76$ & $11.41 \pm 1.30$ & $28.00 \pm 1.80$ \\
\hline
\end{tabular}

Table 5. Contractile properties of free grafts

\begin{tabular}{|c|c|c|c|c|}
\hline $\begin{array}{l}\text { Age } \\
\text { (days) }\end{array}$ & $\begin{array}{l}\text { TwT } \\
(\mathrm{g})\end{array}$ & $\begin{array}{l}\text { LP } \\
\text { (msec) }\end{array}$ & $\begin{array}{l}\text { TCP } \\
(\mathrm{msec})\end{array}$ & $\begin{array}{l}\mathrm{FCT} \\
\text { (msec) }\end{array}$ \\
\hline $\begin{array}{l}2 \\
(n=4)\end{array}$ & $0.41 \pm 0.06$ & $5.20 \pm 0.20$ & $14.78 \pm 1.80$ & $32.65 \pm 1.31$ \\
\hline $\begin{array}{l}4 \\
(n=6)\end{array}$ & $0.91 \pm 0.22$ & $5.23 \pm 0.36$ & $9.83 \pm 0.72$ & $30.23 \pm 1.97$ \\
\hline $\begin{array}{l}7 \\
(n=5)\end{array}$ & $1.81 \pm 0.29$ & $4.81 \pm 0.15$ & $10.84 \pm 0.52$ & $31.62 \pm 1.04$ \\
\hline $\begin{array}{l}14 \\
(n=7)\end{array}$ & $2.82 \pm 0.56$ & $4.77 \pm 0.20$ & $9.64 \pm 0.45$ & $29.81 \pm 0.68$ \\
\hline $\begin{array}{l}30 \\
(n=3)\end{array}$ & $3.40 \pm 1.02$ & $4.23 \pm 0.19$ & $7.60 \pm 0.60$ & $22.70 \pm 2.20$ \\
\hline $\begin{array}{l}60 \\
(n=3)\end{array}$ & $1.76 \pm 0.65$ & $4.43 \pm 0.09$ & $6.97 \pm 0.15$ & $22.00 \pm 1.00$ \\
\hline $\begin{array}{l}90 \\
(n=3)\end{array}$ & $2.67 \pm 1.07$ & $4.87 \pm 0.49$ & $9.93 \pm 1.15$ & $28.83 \pm 3.24$ \\
\hline
\end{tabular}

the contractile times until normal values of the isometric twitch were attained during the second month after transplantation. The normalization of twitch characteristics during the later phases of regeneration differed little between normal and denervated transplants. The average twitch tension of the denervated EDL was consistently greater than that of normal grafts (Table 1 and 3). During the first 2 weeks the tetanic tension was consistently greater in denervated grafts than in the normal ones. 
grafts of the normal soleus muscle

\begin{tabular}{llll}
\hline $\begin{array}{l}\text { HRT } \\
(\mathrm{msec})\end{array}$ & $\begin{array}{l}\text { TetT } \\
(\mathrm{g})\end{array}$ & $\begin{array}{l}\text { Tet TPC } \\
(\mathrm{msec})\end{array}$ & $\begin{array}{l}\text { Wt } \\
(\mathrm{mg})\end{array}$ \\
\hline $44.20 \pm 1.99$ & $4.62 \pm 0.52$ & $89.80 \pm 2.79$ & \\
$36.00 \pm 1.26$ & $3.64 \pm 0.66$ & $75.50 \pm 0.90$ & \\
$34.17 \pm 1.27$ & $10.14 \pm 0.44$ & $49.17 \pm 5.21$ & \\
$41.30 \pm 1.47$ & $6.79 \pm 0.78$ & $93.15 \pm 5.26$ & $52.00 \pm 5.63$ \\
$35.22 \pm 7.58$ & $14.23 \pm 4.80$ & $95.25 \pm 13.48$ & $76.25 \pm 6.84$ \\
$32.51 \pm 6.88$ & $19.05 \pm 3.90$ & $81.00 \pm 14.60$ & $70.30 \pm 9.80$ \\
\hline
\end{tabular}

of the 14-day denervated soleus muscle

\begin{tabular}{llll}
\hline $\begin{array}{l}\text { HRT } \\
(\mathrm{msec})\end{array}$ & $\begin{array}{l}\text { TetT } \\
(\mathrm{g})\end{array}$ & $\begin{array}{l}\text { Tet TPC } \\
(\mathrm{msec})\end{array}$ & $\begin{array}{l}\text { Wt } \\
(\mathrm{mg})\end{array}$ \\
\hline $53.32 \pm 1.93$ & $1.78 \pm 0.26$ & $95.05 \pm 3.55$ & \\
$44.95 \pm 5.38$ & $3.80 \pm 0.79$ & $55.45 \pm 19.85$ & \\
$44.68 \pm 2.76$ & $5.00 \pm 1.11$ & $53.43 \pm 2.63$ & \\
$34.77 \pm 1.41$ & $4.29 \pm 1.42$ & $39.85 \pm 6.61$ & \\
$31.43 \pm 1.92$ & $4.36 \pm 1.24$ & $76.25 \pm 1.75$ & $83.00 \pm 3.00$ \\
$34.70 \pm 3.42$ & $28.98 \pm 1.02$ & $92.00 \pm 3.00$ & $59.33 \pm 15.07$ \\
$39.57 \pm 2.87$ & $18.37 \pm 7.83$ & $\mathbf{7 7 . 1 0} \pm 10.83$ & $73.33 \pm 0.04$ \\
\hline
\end{tabular}

The changes in contractile behavior in the transplanted SOL muscle were in many respects similar to those of the EDL grafts. As was the case with normal EDL grafts, 2 day grafts of normal SOL muscles ( 5 cases) exhibited either no or a minimal contractile response to direct stimulation by $26 \mathrm{~V}$ for $5 \mathrm{msec}$. In succeeding days most characteristics of the twitch underwent a gradual shortening until 60 days, after which time the contraction times became more prolonged (Table 4). The LP was prolonged in all cases except for the 90 day group. This parameter showed the least 
Table 6. Contractile properties of the normal

\begin{tabular}{lllll}
\hline $\begin{array}{l}\text { Postnatal } \\
\text { age } \\
\text { (days) }\end{array}$ & $\begin{array}{l}\text { TwT } \\
(\mathrm{g})\end{array}$ & LP & TPC & FCT \\
\hline $\begin{array}{l}\text { 14 } \\
(n=3)\end{array}$ & $0.65 \pm 0.27$ & $5.90 \pm 0.49$ & $11.70 \pm 1.45$ & $32.40 \pm 1.75$ \\
$\begin{array}{l}(\mathrm{msec}) \\
(n=3)\end{array}$ & $3.77 \pm 0.15$ & $4.17 \pm 0.12$ & $7.97 \pm 0.75$ & $24.43 \pm 1.62$ \\
60 & $5.50 \pm 0.95$ & $3.93 \pm 0.29$ & $10.13 \pm 0.13$ & $26.87 \pm 0.88$ \\
$(n=3)$ & & $4.03 \pm 0.20$ & $14.13 \pm 0.38$ & $37.00 \pm 1.79$ \\
$\begin{array}{l}90 \\
(n=3)\end{array}$ & $16.93 \pm 1.56$ & & & \\
\hline
\end{tabular}

successful recovery of all the twitch characteristics. Compared with normal control SOL muscles (Table 6), the twitch and tetanic tensions of the grafts of normal SOL muscles were very weak (Table 4). In succeeding days the twitch and tetanic tensions gradually increased in strength, but their relative strength as compared with normal control muscles (Table 6) did not attain the same levels as grafts of the denervated EDL. Following the first few days of transplantation, the properties of the twiteh underwent a temporary shortening until 60 days, after which time they become more prolonged.

In summary, there are some contractile responses to free grafting that are common to both the EDL and SOL muscles and others that are characteristic of one, but not the other muscle. When normal muscles are transplanted, both the EDL and SOL are characterized by a temporary loss (or near loss) of contractile powers at 2 days. In both, recovery of contraction begins by 4 days. Grafts of muscles denervated for 14 days prior to transplantation are characterized by the maintenance of contractible ability throughout the early days after transplantation. Transplanted EDL muscles demonstrate a slight prolongation of the twitch during the second week, followed by a speeding-up of the twitch toward normal values at later periods. In SOL grafts, the twitches are slow during the first few days after transplantation. This is followed by a shortening of the contractile times and a subsequent slowing-down at the later periods. The degree of functional return in terms of twitch tension is less in the SOL than in the EDL.

\section{Discussion}

This research demonstrates that free muscle grafts are not only enabled to persist as morphological entities by means of a massive regenerative 
soleus muscle (ontogenetic gradient)

\begin{tabular}{llll}
\hline HRT & TetT & Tet TPC & Wt \\
$(\mathrm{msec})$ & $(\mathrm{g})$ & $(\mathrm{msec})$ & $(\mathrm{mg})$ \\
\hline $49.87 \pm 1.17$ & $4.37 \pm 0.95$ & $99.30 \pm 3.74$ & $7.6 \pm 0.44$ \\
$37.53 \pm 3.95$ & $19.33 \pm 2.00$ & $97.07 \pm \tilde{\mathbf{0} .14}$ & $29.0 \pm 2.1$ \\
$45.00 \pm 1.65$ & $25.97 \pm 4.70$ & $100.07 \pm 1.93$ & $65.0 \pm 6.2$ \\
$54.30 \pm 3.45$ & $81.07 \pm 7.51$ & $96.60 \pm 2.98$ & $109.0 \pm 12.0$ \\
\hline
\end{tabular}

response, but that morphological restoration is accompanied by functional recovery. As a physiological model for studying the development of contractile properties of regenerating muscles, the analysis of free muscle grafts is complicated by the persistence of a few mature muscle fibers around the periphery of the graft during the early days after transplantation. These persisting fibers, although proportionately small in older grafts, account for all of the contractile function of the muscles during the first $4-5$ days following transplantation.

Despite the fact that long term SOL and EDL grafts in the rat are quite similar whether they have been previously denervated or not, a comparison of the early post-transplantation stages reveals some important differences between them. These will be outlined below.

The major differences between normal and denervated grafts occur during the first week after transplantation. On the second day, few normal grafts produced measurable contractions in response to direct electrical stimulation. Those that did, contracted only after a prolonged. stimulus. In contrast, 14 day denervated grafts of both the SOL and EDL were consistently able to contract on the second day. The contractions of both muscles were weak, and the prolonged contraction times reflect denervation changes of the surviving muscle fibers [4]. The histochemical profiles of these early grafts were closely correlated with their functional properties. Particularly when stained for $\mathrm{Ph}$ activity, 2 day grafts of normal muscle possessed only a thin rim of a few active peripheral fibers whereas the rim of activity was markedly wider in denervated grafts [2]. At this time a definitive explanation for the temporary lack of contractile activity in 2 day normal muscle grafts can not be offered. Likely possibilities are a depletion of critical enzymes or substrates, particularly those associated with glycolysis in the case of fast 
muscle grafts, or temporary disturbances in the active transport of inorganic ions which are involved in the contractile process. Recent work [7] has shown a marked temporary decrease of resting membrane potential in the superficial layer of muscle fibers of newly transplanted normal EDL muscles, but not in grafts of denervated muscle. This decrease is correlated with the negligible contractile response observed at that time and may explain, at least in part, the relatively more successful grafting of denervated muscles.

On the basis of their morphology, the regenerating muscle fibers of previously denervated grafts should be able to contact at the end of the first week. Thus the contractile properties after this time would reflect the increasing contributions of the regenerating fibers. According to our previous investigation of regenerating muscle [1], the quantitative contribution of regenerating muscle at 7 days would be slight. By 14 days, particularly in a fast muscle, the contraction time should be somewhat prolonged because any muscle fibers still surviving from the original muscle would have been denervated from the time of grafting, and also the contraction times of the newly regenerating muscle fibers are greatly prolonged. After 14 days, the contraction times of the regenerates begin to speed up in the case of the FDL. This can be attributed to the gradual maturation of the regenerating muscle fibers as well as the reinnervation of the graft. Because the development of contractile properties in a pure population of regenerating slow muscle fibers has not yet been investigated, interpretation of the functional maturation of SOL transplants is less certain.

In older transplants, denervated EDL grafts were consistently able to exert greater twitch tension than their normal graft counterparts. This is most likely a reflection of the greater destruction and lesser regeneration of muscle fibers in normal grafts. In the SOL the difference was less pronounced and can probably be explained by the smaller diameter of the normal SOL muscle. This allows a more rapid revascularization of the grafts and less loss of tissue in the center of the grafts.

In summary, free grafting of previously denervated muscle is followed not only by the regeneration and subsequent maintenance of striated muscle fibers within the graft, but by a significant restoration of the contractile times and strength of the muscles. The free grafting of denervated muscles merits further attention as a possible technique for dealing with the restoration of muscles damaged by either trauma or disease.

Acknowledgments. This work was partially supported by grants from the Muscular Dystrophy Association of America. Much of the research was carried out during the course of scientific exchange visits sponsored by the Academies of Sciences of Czechoslovakia and the United States. 


\section{References}

1. Carlson, B. M., Gutmann, E. : Development of contractile properties of minced muscle regenerates in the rat. Exp. Neurol. 36, 239-249 (1972)

2. Carlson, B. M., Gutmann, E. : Transplantation and cross-transplantation of free muscle grafts in the rat. Experentia (Basel) (in press, 1974).

3. Gutmann, E., Carlson, B.: Contractile and histochemical properties of regenerating cross-transplanted fast and slow muscles in the rat. Pflügers Arch. 353, 227-339 (1975)

4. Gutmann, E., Melichna, J., Syrovy, I.: Contraction properties and ATPase activity in fast and slow muscle of the rat during denervation. Exp. Neurol. 36, $488-497(1972)$

5. Rohlíček, V., Gutmann, E.: The constant of contraction time, a new expression of maximal rate of tension development. Physiol. bohemoslov. 21, 430-431 (1972)

6. Studitsky, A. N., Zhenevskaya, R. P.: Theory and practice of the auto- and homotransplantation of muscles. Moscow: Publ. House Nauka 1967

7. Vyskočil, F., Carlson, B., Gutmann, E.: Changes in resting membrane potential and contractility of innervated and denervated skeletal muscle free grafts in the rat. Pflügers Arch. 344, 181-186 (1973)

8. Zhenevskaya, R. P.: Transplantation of skeletal muscles in animals (Russian). Usp. sovrem. Biol. 65, 133-143 (1968)

9. Zhenevskaya, R. P.: Neurotrophic regulation of the plastic activity of muscular tissue (Russian). Moscow : Tzdatel. Nauka 1974

Dr. Bruce M. Carlson

Department of Anatomy

4622 Medical Sciences II

University of Michigan

Ann Arbor, MI 48104/U.S.A. 